\title{
Operation Blackbuck
}

\section{Anne Wright}

In July 1970, at the request of the author, who is one of our FPS representatives in India, the FPS gave $£ 200$ to buy blackbuck with which to start a breeding herd of this rapidly disappearing Indian antelope. She describes how seven animals were successfully released in the newly created Bandhavghar National Park, at Rewa, in Madhya Pradesh.

The idea of collecting the nucleus of a breeding herd of blackbuck at Rewa in Madhya Pradesh dates back to a glorious afternoon in May 1970 , when my daughter, Belinda, and I visited the newly formed Bandhavghar National Park as the guests of His Highness the Maharaja of Rewa. Accompanied by Dr Terry Walton, now full-time zoological advisor to the Maharaja, we drove down the forest road through rich sal and bamboo, and caught our first sight of Bandhavgarh Fort, the fabulous ancient capital of the rulers of Rewa, which they occupied from the 12th to the 16th century. Even Viceroys who came to hunt tiger at Rewa in the old days of the British Raj were not invited to visit the old fort, and we were the first Europeans, apart from Terry Walton, to enter the huge gateway. The fort, which dominates the surrounding forests, stands in the centre of the national park on a high plateau, four square miles in extent and 2600 feet above sea level, with its own water supply from two lakes, and safe from tiger and leopard which cannot climb the 500-foot cliffs surmounted by ancient walls.

Here Terry Walton released a pair of blackbuck, but, he told us, he could not get any more; he had even written to Texas. Blackbuck in their thousand once roamed the plateau areas of Rewa State, but, as in the rest of India, they have been almost wiped out and are now in danger of extinction. It occurred to me then that the Fauna Preservation Society might support a project to start a small breeding herd for Rewa.

The scene then shifts to London in July, and a taxi speeding towards South Kensington, which I nearly asked to turn back, in order to avoid the frightening prospect of facing the eminent Council of the Fauna Preservation Society! However, at the meeting in the British Museum the question of funds for a herd of blackbuck came up, the Chairman supported it, questions were asked and answered, and £200 was generously given.

The next phase of Operation Blackbuck took longer; it was six months before we finally collected a herd of eight animals. Four does were bought quite quickly from the Calcutta Animal Market. (Although reluctant to support this trade it seemed worse to let them be sold for their skins and meat.) These we kept in our garden, and the only tragedy was the untimely death of the smallest one which appeared to be suffering from a calcium deficiency. The rest thrived on napier grass, crotons, hibiscus, the leaves of a militia tree and crushed oats from our 
Wallace very generously gave us the money to hire a lorry to transport the buck five hundred miles to Rewa.

There were delays and difficulties, but at last we saw the loaded lorry off to Shantineketan and we followed by car. But the lorry did not arrive and we had an anxious night. However, it appeared in the morning, in pouring rain, having taken refuge at a petrol station during the night. Due to the unsettled state of West Bengal, police barriers had had to be negotiated, and on the day that we reached Shantineketan Naxalite extremists had burned down the local school and library. We met convoys of troops moving into the district.

The Ballavpur Deer Park and experimental plantation at Shantineke$\tan$ is a tribute to the Forest Department. Started some fifteen years ago, trees have grown successfully in the bare red laterite soil. The blackbuck were still very wild and we were thankful to have Mr R.K. Lahiri, Wildlife Officer of West Bengal with us. With the help of six Santhal tribals they were manhandled as gently as possible into the crates. Two of the three does were carrying young, and unfortunately one of them died later, no doubt as a result of the long drive to Rewa. But the rest were safely released in the national park, on the plateau of Bandhavghar Fort. Terry Walton has since described how, when he visited them one morning at dawn, all skipped away - except Mala, one of the animals from our garden, who tried to follow the jeep.

The establishment of this 40-square mile national park was largely thanks to the present Maharaja of Rewa. His family have always been great hunters and their trophies fill the palaces, but shortly after the capture of Mohan, the famous white tiger, the present Maharaja disposed of his guns and gave up shooting to devote his life to conservation, particularly of tiger. One of his first actions was to protect his private reserves; much later, when this area merged with Madya Pradesh, he insisted that Bandhavghar be declared a national park. This was achieved in March 1969, in an all-time record time of nineteen days from when he laid the plan before the Madya Pradesh Government. Through his personal efforts all felling of timber and cattle grazing were stopped and the park became one of India's five recognised national paiks, with bison, tiger, bear, and a remarkable number of sambhar. I saw chinkara and four-horned deer in the more open forest land to the south.

The fort is .certainly a tourists' paradise of the future with its old gates, ruined temples and carvings of great antiquity, notably a gigantic tortoise, a Hanuman and a thirty-foot long deity carved from solid rock.

It is on the plateau in this romantic setting, protected by the ancient walls, that our breeding herd of blackbuck are released, the only blackbuck in a vast area where three decades ago they were to be found in herds of thousands.

\section{Guide to Indian Mammals}

A revised edition of S.H. Prater's valuable Indian Mammals is published by the Bombay Natural History Society (Rs 30). The illustrations include 28 colour plates. 